\title{
Antibiotic Clinic: Two Years' Experience in Outpatient Parenteral Antimicrobial Therapy in a Portuguese Hospital
}

\author{
Clínica do Antibiótico: Dois Anos de Experiência \\ em Outpatient Parenteral Antimicrobial Therapy \\ num Hospital Português
}

\author{
Joana RIGOR $\rrbracket^{1}$, Paula Marques FERREIRA¹, Fábio MURTEIRA', Cristóvão FIGUEIREDO², Nuno VIEIRA ${ }^{3}$, \\ Rosa OLIVEIRA ${ }^{3}$, Raquel COUTO², Margarida MOTA $1,2,3$ \\ Acta Med Port 2019 Sep;32(9):576-579 - https://doi.org/10.20344/amp.11730
}

\section{ABSTRACT}

Introduction: Outpatient antimicrobial therapy programs have been in place for more than four decades. They provide safe and effective treatment for a selected group of patients while reducing costs. In Europe in general, and in Portugal in particular, these programs are still a relatively new phenomenon. The aim of this study is to describe our center's two years' experience with such a program (Antibiotic Clinic).

Material and Methods: The cohort of treatments administered by the Antibiotic Clinic in its first two years of existence (September $12^{\text {th }}$ 2016 to September $11^{\text {th }}$ 2018) was analyzed and data pertaining to patients, infections, infectious agents, antimicrobials and outcomes (infection resolution, adverse events and death) were characterized.

Results: The Antibiotic Clinic treated 231 patients in 250 episodes, providing a total of 2357 days of antibiotic treatment. The urinary tract was the most common site (39.2\%) and Enterobacteriaceae the most common agents $(63.7 \%$ of isolates). Infections were resolved in $90.8 \%$ of treatments $(95.6 \%$ of patients), adverse events were few $(1.2 \%)$ and direct mortality was not found. The dropout rate was $1.6 \%$.

Discussion: Infection resolution and adverse event rates were comparable to other centers. High treatment and low dropout rates point to high physician and patient acceptance.

Conclusion: Our experience with this program suggests it is a safe and effective alternative to inpatient admission. This is in line with current literature which suggests efforts should be made to expand this treatment modality.

Keywords: Ambulatory Care; Anti-infective Agents; Antibacterial Drug Resistance; Infection/drug therapy; Outpatients; Portugal

\section{RESUMO}

Introdução: Os programas de administração de antimicrobianos parentéricos em ambulatório (outpatient parenteral antimicrobial therapy) iniciaram-se há mais de quatro décadas. Para além de proporcionarem tratamento seguro e eficaz num grupo selecionado de doentes, permitem também a redução de custos. Na Europa, e em particular em Portugal, a implementação destes programas é um fenómeno recente. O objetivo deste estudo é descrever dois anos de experiência de Clínica do Antibiótico.

Material e Métodos: Foram incluídos todos os doentes tratados na Clínica do Antibiótico nos dois primeiros anos de existência (12 de setembro de 2016 a 11 de setembro de 2018), sendo descritas variáveis relativas à população, infeções, agentes infeciosos, tratamentos e outcomes (resolução de infeção, eventos adversos e morte).

Resultados: A Clínica do Antibiótico tratou 231 doentes em 250 episódios, garantindo 2357 dias de antibioterapia. O local de infeção mais comum foi o trato urinário $(39,2 \%)$ e os agentes mais comuns foram as Enterobacteriaceae (63,7\% dos isolamentos). Obteve-se resolução da infeção em $90,8 \%$ dos tratamentos (95,6\% dos doentes), ocorreram poucos eventos adversos $(1,2 \%)$ e a mortalidade direta foi nula. Houve uma taxa de abandono de $1,6 \%$.

Discussão: As taxas de resolução e de complicações foram comparáveis às de outros centros. Elevado número de tratamentos e baixa taxa de abandono apontam para boa aceitação por médicos e doentes.

Conclusão: A nossa experiência sugere ser uma alternativa eficaz e segura ao tratamento em internamento. Estes resultados estão de acordo com a literatura, sugerindo que esforços deverão ser feitos para expandir a utilização destes programas.

Palavras-chave: Anti-Infecciosos; Assistência Ambulatorial; Doentes Ambulatoriais; Farmacorresistência Bacteriana; Infecção/tratamento; Portugal

\section{INTRODUCTION}

Outpatient parenteral antimicrobial therapy (OPAT) programs provide intravenous antibiotic treatment, in at least two doses on different days, without the need for inpatient hospital admission, in selected patients and clinical situations. ${ }^{1}$ This treatment modality has existed in the United States of America since the 1970's, as a means of ensuring treatment to all patients while working with gaps in medical insurance coverage. ${ }^{2}$ Since then, the safety and efficacy of these programs have been demonstrated numerous times, as they have been associated with a low rate of complications, reduced hospital stays and overall cost savings when compared to inpatient treatment. ${ }^{3-8}$

In Europe, OPAT is still underused, and significant asymmetries between countries exist. ${ }^{9}$ In a report analyzing data from 20 European countries in 2006, parenteral

1. Serviço de Medicina Interna. Centro Hospitalar de Vila Nova de Gaia/Espinho. Vila Nova de Gaia. Portugal.

2. Unidade de Doenças Infeciosas. Serviço de Medicina Interna. Centro Hospitalar de Vila Nova de Gaia/Espinho. Vila Nova de Gaia. Portugal.

3. Grupo Coordenador Local. Programa de Prevenção e Controlo de Infeções e Resistência aos Antimicrobianos. Centro Hospitalar de Vila Nova de Gaia/Espinho. Vila Nova de Gaia. Portugal.

$\triangle$ Autor correspondente: Joana Rigor. joanarigor@gmail.com

Recebido: 23 de dezembro de 2018 - Aceite: 12 de março de 2019 | Copyright @ Ordem dos Médicos 2019 
administration represented $>1 \%$ of total outpatient antimicrobial use in only three countries (Russia, Italy and Poland). Also noted were the differences in type of drugs and modality of treatment across the continent. Portugal, while the country with the fifth highest rate of outpatient antibiotic use by defined daily dose per 1000 inhabitants per day, ranked ninth in total parenteral outpatient antibiotic use. ${ }^{9}$ However, this data did not discriminate the setting of outpatient antibiotic use and to date, to the best of our knowledge, no analysis of a Portuguese OPAT program has been published.

Vila Nova de Gaia/Espinho Hospital Centre is a tertiary public hospital with over 500 patient beds, serving a population of 700000 inhabitants. The Antibiotic Clinic of Vila Nova de Gaia/Espinho Hospital Centre was created in September $12^{\text {th }} 2016$. It is run by the Infectious Diseases Unit (IDU) of the Internal Medicine Department, with the support of the hospital center's group for the state national Program for the Prevention and Control of Infections and Antimicrobial Resistance (Grupo Coordenador Local do Programa de Prevenção e Controlo de Infeções e de Resistência aos Antimicrobianos - GCL-PPCIRA). The aims of the Antibiotic Clinic are to ensure administration of parenteral antimicrobial in an outpatient setting, to promote measures for the appropriate use of antimicrobials, to provide counselling on antimicrobial therapy for inpatients, to ensure the clinical follow-up of outpatients with infections, to shorten inpatient stays and to reduce overall infection rates and associated costs.

Adult patients that are capable of daily visits to the hospital, presenting with infections that can be managed with once-daily antimicrobial drugs, are eligible for the Clinic. Patients are required to be clinically stable, and they or their family members/caretakers must give consent, commit to the clinical plan, and be able to monitor for and report possible complications. Preferably, an infectious agent or agents should be identified, and no appropriate oral alternative must be available.

Any physician from the Hospital Centre or local Primary Care Unit may refer a patient from the Emergency Department (ER), outpatient clinic or inpatient ward, after diagnosis and first observed administration of a parenteral antimicrobial agent. During the first appointment, the physician from the IDU confirms the diagnosis and establishes a treatment and follow-up plan. Antibiotics are injected via peripheral venous catheter, which is introduced and removed every day of treatment. Although daily venipunctures might be unpleasant for patients, this method was preferred to peripheral inserted central catheters (PICC) since most treatments were expectably short-term, use of PICC is more costly and management of these lines requires more care, especially from the patient or caretaker, possibly limiting patient selection. The patient is periodically examined by the medical team, on a programmed and/or need basis, and in the latter as requested by the patient or nursing team.

The goal of this study is to present our experience with a new OPAT program, to compare our results to more experienced centers, and to contribute to the discussion of the feasibility of nationwide expansion of OPAT.

\section{MATERIAL AND METHODS}

All treatments administered in the Antibiotic Clinic in its first two years of existence (from September $12^{\text {th }} 2016$ to September $11^{\text {th }}$ 2018) were included, and data was acquired by clinical file consultation. Variables pertaining to patients, infections, microbes and antimicrobial agents were collected. Age, gender and number of comorbidities were registered; the Charlson Comorbidity Index was used to best characterize overall morbidity. ${ }^{10}$ Site of infection and, when possible, infectious agents were listed; multidrug-resistant (MDR), extensively drug-resistant (XDR) and pandrug-resistant (PDR) bacteria were classified according to the proposal by Magiorakos et al. ${ }^{11}$ Regarding treatment, antimicrobial drugs and duration of treatment were described. Data are presented in median and interquartile range (IQR) or percentage, as appropriate.

The study was approved by the Ethics Committee of Centro Hospitalar de Vila Nova de Gaia/Espinho.

\section{RESULTS \\ Population demographics}

A total of 250 episodes occurred, which corresponded to 231 patients. There was a $21,2 \%$ increase in the number of treatments in the second year. The population was predominantly male $(56.4 \%)$ with a median age of 63 [interquartile range (IQR) of 28] years. Almost half of the patients (48.1\%) were elderly (age $\geq 65$ years). Multiple comorbidities were common $(82.3 \%$ with $\geq 2)$, and the Charlson Comorbidity Index had a median of 3 (IQR 5).

Referral was made after observation in the ER (48.8\%), ward $(28.4 \%)$ and outpatient appointment (22.8\%). By medical specialty, most patients were referred by Internal Medicine $(72.0 \%)$, followed by Urology $(8.0 \%)$ and General Surgery (3.6\%).

\section{Infections}

By site, urinary tract infections were the most prevalent $(39.2 \%)$, followed by skin and soft-tissue $(16.4 \%)$ and respiratory tract infections $(12.8 \%)$. The most common infection was pyelonephritis, accounting for over a quarter (26.4\%) of total. One patient was found to have no infection and as such did not receive treatment. Infections by organ system are listed in Table 1.

\section{Infectious agents}

In most cases (57.2\%), the infectious agent was identified by laboratory methods. A total of 181 positive results were obtained; urine yielded $81(44.8 \%)$, blood $49(27.1 \%)$ and aspirate or tissue biopsy $32(17.7 \%)$, while the remaining were found in cerebrospinal fluid $(4.4 \%)$, bronchoalveolar fluid $(3.3 \%)$, bronchial secretions $(1.7 \%)$ and fecal samples $(1.1 \%)$.

Regarding infectious agents, 168 were identified (Table 2). Enterobacteriaceae were the most frequently found 
(63.9\%). Two species were implicated in over half (53.0\%): Escherichia coli with $28.6 \%$ and Klebsiella pneumoniae with $24.4 \%$. Antibiotic resistance was common. Of the 139 isolates with known antibiogram, multidrug-resistant (MDR) isolates predominated with $48.9 \%$, of which $60.3 \%$ were possible extensively drug-resistant (XDR). There were no confirmed XDR or pandrug-resistant (PDR) isolates.

\section{Antimicrobial treatment}

The Antibiotic Clinic administered a total of 2357 days of antimicrobials, with a median of 7 (IQR 7) days per treatment. Monotherapy was preferred in $80.4 \%$ of treatments. In total, 305 antimicrobials were prescribed (Table 3). The most frequent were ceftriaxone (49.5\%) and ertapenem (25.9\%), the first most often as empirical treatment for community acquired infections of skin and soft-tissue and urinary tract, the latter mostly in situations of current or previous resistance to other drugs.

Table 1 - Infections by organ system

\begin{tabular}{lc}
\hline Infection site & Number of treatments, $\mathbf{n}(\%)$ \\
\hline Abdominal & $18(7.2 \%)$ \\
Bone and joint & $11(4.4 \%)$ \\
Cardiovascular & $5(2.0 \%)$ \\
Central nervous system & $9(3.6 \%)$ \\
Ear, nose and throat & $6(2.4 \%)$ \\
Genital and sexually transmitted & $11(4.4 \%)$ \\
Respiratory system & $32(12.8 \%)$ \\
Skin and soft-tissue & $41(16.4 \%)$ \\
Urinary tract & $98(39.2 \%)$ \\
Systemic/unknown & $18(7.2 \%)$ \\
No infection & $1(0.4 \%)$ \\
\hline
\end{tabular}

Table 2 - Infectious agents identified

\begin{tabular}{lc}
\hline Infectious agent & Prevalence, $\mathbf{n}(\%)$ \\
\hline Bacterial & $162(96.4 \%)$ \\
Enterobacteriaceae & $107(63.7 \%)$ \\
Enterococcus & $8(4.8 \%)$ \\
Staphylococcus & $9(5.4 \%)$ \\
Streptococcus & $15(8.9 \%)$ \\
Other bacterial & $23(13.7 \%)$ \\
Fungi & $5(3.0 \%)$ \\
Parasites & $1(0.6 \%)$ \\
\hline
\end{tabular}

Table 3 - Antimicrobial treatment by class

\begin{tabular}{lc}
\hline Antimicrobial & Treatment courses, $\mathbf{n}(\%)$ \\
\hline Aminoglycosides & $21(6.9 \%)$ \\
Carbapenems & $80(26.2 \%)$ \\
Cephalosporins & $152(49.8 \%)$ \\
Lincosamides & $10(3.3 \%)$ \\
Macrolides & $9(3.0 \%)$ \\
Quinolones & $8(2.6 \%)$ \\
Other antibacterial & $20(6.6 \%)$ \\
Anti-fungal & $5(1.6 \%)$ \\
\hline
\end{tabular}

\section{Complications and outcomes}

There were three (1.2\%) known cases of direct complications related to the antibiotic: one case of generalized malaise, one of thrombocytopenia and another of Clostridium difficile infection. The first two resolved spontaneously and did not warrant discontinuation of therapy; the third was successfully treated with oral antibiotics.

Four (1.6\%) patients required admission as inpatients, three for drainage of abscess (hepatic, pulmonary and renal) and the fourth because of worsening febrile neutropenia. Another $(0.4 \%)$ patient had a cutaneous abscess requiring drainage in the $E R$.

The outcome was favorable in $90.8 \%$ of treatments. Of the $13(5.2 \%)$ cases of worsening or relapse, all were resolved on subsequent treatment; overall, $95.6 \%$ of patients were cured. Four (1.6\%) patients were lost to follow-up and one $(0.4 \%)$ died from an unrelated cause (lymphoma). Three (1.2\%) patients are currently still being treated and are improving.

\section{DISCUSSION}

In the two years since its creation, the Antibiotic Clinic of Vila Nova de Gaia/Espinho Hospital Centre provided 250 treatments to 231 patients, many of them elderly and most having various comorbidities. Considering the hospital size, the number of treatments was comparable to other series. $^{12-15}$

Urinary tract infection was more prevalent $(39.2 \%$ vs $4.45 \%-23.7 \%),{ }^{15-17}$ and skin and soft-tissues infections were less prevalent $(16.4 \% \text { vs } 53 \%-61.28 \%)^{14,16,17}$ than what is described in the literature; the type of infections treated varies greatly from center to center, as protocols differ. Infectious agents and antibiotic resistance reflected local patterns, with significant rates of MDR and possible XDR agents. ${ }^{18}$

Despite population and infectious agent characteristics, the rate of complications was lower than previously described $(1.2 \%$ vs $2.7 \%-9.8 \%))^{3,13,14,16,19}$ Of note, in our population, patients were not directly questioned about adverse effects and only those warranting medical attention were reported. Also, peripheral catheters were removed at the end of each antibiotic administration, minimizing line-related complications. There were no infection-related deaths, which is consistent with the findings of several cohorts. ${ }^{3,14,17}$ As with other centers, resolution of infection was the norm (90.8\% vs $84 \%-92.4 \%)$. . $^{3,13-15,17}$

Restriction to one-a-day parenteral administration was a limitation, as it influenced antibiotic selection in cases where antimicrobial susceptibility was known. However, this only affected a small percentage $(8.2 \%)$ of treatments.

No direct cost analysis was performed. Nevertheless, 2357 days of therapy were provided, which theoretically represent 2357 days of inpatient costs saved. Also, almost half $(48.8 \%)$ of patients were referred from the ER and, as such, were never admitted as inpatients. Community-dwelling young patients might be able to remain productive, which adds to the lowering of overall expenditure. OPAT therapy 
permits reallocation of beds to other patients in need, reducing wait times and indirectly generating savings. ${ }^{7,20,21}$

Despite being a new program in the hospital, the Antibiotic Clinic provided a high number of treatments and experienced significant growth in its second year. The dropout rate was a mere $1.6 \%$. This suggests a high physician and patient acceptance of the program, which should be confirmed by satisfaction questionnaires.

\section{CONCLUSION}

To the best of our knowledge, this is the first study describing an OPAT program in Portugal. According to the current literature, OPAT is a safe and cost-effective way to treat selected patients and clinical situations. The Antibiotic Clinic of Vila Nova de Gaia/Espinho Hospital Centre is recent but growing and has already served a sizeable population, possibly reflecting a high physician acceptance of the program. Rates of success and complications were comparable to those of more established centers, and point to the feasibility of OPAT, even in its initial phases. Other than site of infection most frequently treated, there were no major differences between our data and that from other series worldwide. Our work adds to the growing body of studies that favors the widespread application of similar programs

\section{REFERENCES}

1. Norris AH, Shrestha NK, Allison GM, Keller SC, Bhavan KP, Zurlo JJ, et al. 2018 Infectious Diseases Society of America Clinical Practice Guideline for the Management of Outpatient Parenteral Antimicrobial Therapy. Clin Infect Dis. 2019;68:e1-35.

2. Williams DN, Baker CA, Kind AC, Sannes MR. The history and evolution of outpatient parenteral antibiotic therapy (OPAT). Int $\mathrm{J}$ Antimicrob Agents. 2015;46:307-12.

3. Seetoh T, Lye DC, Cook AR, Archuleta S, Chan M, Sulaiman Z, et al. An outcomes analysis of outpatient parenteral antibiotic therapy (OPAT) in a large Asian cohort. Int J Antimicrob Agents. 2013;41:569-73.

4. Schmidt M, Hearn B, Gabriel M, Spencer MD, McCurdy L. Predictors of unplanned hospitalization in patients receiving outpatient parenteral antimicrobial therapy across a large integrated healthcare network. Open Forum Infect Dis. 2017;4:ofx086.

5. Nguyen $\mathrm{HH}$. Hospitalist to home: outpatient parenteral antimicrobial therapy at an academic center. Clin Infect Dis. 2010;51:S220-3.

6. Yong C, Fisher DA, Sklar GE, Li SC. A cost analysis of Outpatient Parenteral Antibiotic Therapy (OPAT): an Asian perspective. I Int J Antimicrob Agents. 2009;33:46-51.

7. Vargas-Palacios A, Meads DM, Twiddy M, Czoski Murray C, Hulme C, Mitchell ED, et al. Cost-effectiveness of outpatient parenteral antibiotic therapy: a simulation modelling approach. J Antimicrob Chemother. 2017;72:2392-400.

8. Mitchell ED, Czoski Murray C, Meads D, Minton J, Wright J, Twiddy M. Clinical and cost-effectiveness, safety and acceptability of community intravenous antibiotic service models: CIVAS systematic review. BMJ Open. 2017;7:e013560.

9. Coenen S, Muller A, Adriaenssens N, Vankerckhoven V, Hendrickx E, Goossens H. European Surveillance of Antimicrobial Consumption (ESAC): outpatient parenteral antibiotic treatment in Europe. J Antimicrob Chemother. 2009;64:200-5.

10. Charlson M, Szatrowski TP, Peterson J, Gold J. Validation of a combined comorbidity index. J Clin Epidemiol. 1994;47:1245-51.

11. Magiorakos AP, Srinivasan A, Carey RB, Carmeli Y, Falagas ME, Giske $C G$, et al. Multidrug-resistant, extensively drug-resistant and pandrugresistant bacteria: an international expert proposal for interim standard definitions for acquired resistance. Clin Microbiol Infect. 2012;18:268-81. and makes the case for nationwide expansion of OPAT. Still, a cost-efficiency and patient satisfaction analysis is lacking, and results can only be inferred by comparison with other countries. In the future we expect to continue expanding the program and to explore other modalities of treatment, such as at-home and self-administering systems.

\section{PROTECTION OF HUMANS AND ANIMALS}

The authors declare that the procedures were followed according to the regulations established by the Clinical Research and Ethics Committee and to the Helsinki Declaration of the World Medical Association.

\section{DATA CONFIDENTIALITY}

The authors declare having followed the protocols in use at their working center regarding patients' data publication.

\section{CONFLICTS OF INTEREST}

All authors report no conflict of interest.

\section{FUNDING SOURCES}

This research received no specific grant from any funding agency in the public, commercial, or not-for-profit sectors.

12. Chapman AL, Dixon S, Andrews D, Lillie PJ, Bazaz R, Patchett JD. Clinical efficacy and cost-effectiveness of outpatient parenteral antibiotic therapy (OPAT): a UK perspective. J Antimicrob Chemother. 2009;64:1316-24.

13. Upton A, Ellis-Pegler RB, Woodhouse A. Outpatient Parenteral Antimicrobial Therapy (OPAT): a review of experience at Auckland Hospital. N Z Med J. 2004;117:U1020.

14. Barr DA, Semple L, Seaton RA. Outpatient parenteral antimicrobial therapy (OPAT) in a teaching hospital-based practice: a retrospective cohort study describing experience and evolution over 10 years. Int J Antimicrob Agents. 2012;39:407-13.

15. Baharoon $\mathrm{S}$, Almodaimeg $\mathrm{H}, \mathrm{Al}$ Watban $\mathrm{H}, \mathrm{Al}$ Jahdali $\mathrm{H}$, Alenazi $\mathrm{T}, \mathrm{Al}$ Sayyari A, et al. Home intravenous antibiotics in a tertiary care hospital in Saudi Arabia. Ann Saudi Med. 2011;31:457-61.

16. Li W, Branley J, Sud A. Outpatient parenteral antibiotic therapy in a suburban tertiary referral centre in Australia over 10 years. Infection. 2018;46:349-55.

17. Durojaiye OC, Bell H, Andrews D, Ntziora F, Cartwright K. Clinical efficacy, cost analysis and patient acceptability of outpatient parenteral antibiotic therapy (OPAT): a decade of Sheffield (UK) OPAT service. Int J Antimicrob Agents. 2018;51:26-32.

18. European Centre for Disease Prevention and Control. Antimicrobial resistance surveillance in Europe 2016. Annual Report of the European Antimicrobial Resistance Surveillance Network (EARS-Net). Stockholm: ECDC; 2017.

19. Keller SC, Williams D, Gavgani M, Hirsch D, Adamovich J, Hohl D, et al. Rates of and risk factors for adverse drug events in outpatient parenteral antimicrobial therapy. Clin Infect Dis. 2018;66:11-9.

20. Psaltikidis EM, Silva EN, Bustorff-Silva JM, Moretti ML, Resende MR. Economic evaluation of outpatient parenteral antimicrobial therapy: a systematic review. Expert Rev Pharmacoecon Outcomes Res. 2017; 17:355-75.

21. Wai AO, Frighetto L, Marra CA, Chan E, Jewesson PJ. Cost analysis of an adult outpatient parenteral antibiotic therapy (OPAT) programme. A Canadian teaching hospital and Ministry of Health perspective. Pharmacoeconomics. 2000;18:451-7. 